\title{
突出条件下の埋設管に作用する土圧
}

\section{EARTH PRESSURE ON BURIED PIPES UNDER PROJECTION CONDITION}

\author{
島村一訓*・西尾宣明**・高木宣雄*** ·兵藤元宣**** \\ By Kazunori SHIMAMURA, Nobuaki NISHIO, Nobuo TAKAGI and Motonobu HYODO
}

\begin{abstract}
The excess earth pressure works on the buried pipes when they project into the surrounding soils due to the settlement of the soils. This paper describes the review of the formulas to estimate this earth pressure and the results of the experimental studies. The comparison of the observed earth pressures with estimated ones shows that the earth pressure on buried pipes under projection condition is most appropriately estimated by the formula in which the circular slip surface is assumed and Kotter's equation is solved along this slip surface.
\end{abstract}

Keywords : buried pipe, earth pressure, projection condition

\section{1.はじめに}

周辺地盤の沈下などにより埋設管が周辺地盤に対して 突出した状態になると, 埋設管には土被り王以上の土圧 が作用する．この土圧を合理的に評価することは埋設管 を設計，維持管理していくうえで重要である.たとえば, 既存の埋設管の下部に開削工法によって新たな地中構造 物を構築する際には埋設管は掘削により露出し, 工事完 了後に再び埋め戻される.この埋め戻し土の沈下によつ て埋設管が沈下し，変形することを防ぐために，新たな 地中構造物の上に支柱を設け，その支柱の上に埋設管を 載せて埋設管を防護する工法がとられている.このとき， 沈下する周用の地盤に対して相対的に管は突出状態とな り，大きな土圧を受けるようになるので，支柱の設計や 埋設管の安全性の検討のために突出状態のもとで管に作 用する土圧の合理的な算定が必要である. また, 埋設管 がマンホールなどの構造物に接合されている箇所で地盤

* 正会員 MS 東京ガス (株) 技術研究所導管技術研究 室係長研究員 ( 105 港区芝浦 1-16-25)

** 正会員 東京ガス (株) 技術研究所導管技術研究室室長 (同上)

*** 正会員 工修 東京ガス (株) 技術研究所導管技術研究 室課長格研究員 (同上)

**** 正会員 東京ガス (株) 技術研究所導管技術研究室研究 員 (同上)
沈下が生じる場合にも埋設管は周辺地盤に対して突出す る状態になる.このような箇所での接合方法や埋設管の 応力を検討するために, 同様に, 突出状態での土王を知 る必要がある.さらに，軟弱地盤上の盛土下に杭基礎で カルバートを構築する場合にもカルバートや杭基礎を設 計するにあたっって同種の問題が生じる。

さて，埋設管に作用する土圧は，1910～1950 年にか けて Marston と Spangler によってはじめて体系的に研 究された. 彼らは埋設管と周辺地盤との間の相対変位の 方向によって埋設管の設置状態を突出型と溝型に分け, それぞれの場合について土圧算定式を提案した。彼らの 理論は比較的簡明で, 現在でも埋設管設計計算の基礎に なっている.

Marston-Spangler 理論について, 原理上, 使用上の 問題点があることは多くの研究者により指摘されてい る(1)4). また, 突出条件での土圧に限れば新たな算定式 もこれまでにいくつか提案されている.しかしながら， それらも Marston-Spangler 理論にかわる新たな土王算 定式の位置を占めるまでには至っていないのが現状であ ろう. その理由は実規模での実験による十分な裏付けが 示されていないこと, また, 採用されている仮定の妥当 性の検討が十分とはいえないことなどにあるものと考え られる（厳密にいえば, 直接, 埋設管の土圧計算を目的 
として提案されたものは少ない，という事実もある). そこで本研究では, 突出条件下での実規模実験結果をも とに既往の土圧算定式を比較, 検討した。 また，実験で 観察されたすべり面の形状を円弧で近似し，これに Kötter の方程式を適用して土圧を求める解析の結果と も比較した。

実験データとしては, 小口径 $(80 \sim 200 \mathrm{~mm})$ に対し ては加室ら5)のものがあり，それに著者らの実験（口径 200 600 mm）を加えて小口径から中口径の管までの一 連のデー夕を得ることができた。

以下，最初に既往の土圧算定式および円弧すべり面を 仮定した著者らの算定式についてその内容, 特徵を吟味 し, 次に実験結果について述へ，さらに各土圧算定式と 実駼結果の適合性を調べる.

\section{2. 突出条件での土圧算定式}

\section{（1）Marston-Spangler の突出条件土圧算定式}

埋設管が周辺地盤に対して突出する状態のときに埋設 管に作用する土圧を算定するにあたって MarstonSpangler ${ }^{6), 7)}$ は埋設管の側部より上方に伸びる鉛直せん 断面を想定した．そして，この面の両側での変位量の差 によってせん断抵抗力が生じ，埋設管に作用する土圧を 増加させると考えて土圧算定式を導いた．彼らの土玤算 定式は鉛直せん断面が地表まで到達するか否かによって 完全突出条件と不完全突出条件に分かれている.

埋設管の土被りが浅い場合には鉛直せん断面は地表面 まで達する．この状態が完全突出条件であり，土被り圧 で正規化した土圧は

$$
\frac{\sigma_{v}^{\prime}}{\gamma H}=\frac{B_{c}}{H} \cdot \frac{\exp \left(2 K \mu^{\prime} \cdot H / B_{c}\right)-1}{2 K \mu^{\prime}}
$$

で表わされる.ここに, $\sigma_{v}^{\prime}$ : 平均鈆直土圧 (以下ダッシュ は有効応力表示を意味する), $\gamma$ : 土の単位体積重量, $H$ : 管頂での土被り高, $B_{c}$ : 管の外径, $K$ : 土圧係数, $\mu^{\prime}$ : 摩擦係数,である. $K, \mu^{\prime}$ の值には $K=\left(1-\sin \phi^{\prime}\right) /$ $\left(1+\sin \phi^{\prime}\right)$ (ランキンの主働土压係数), $\mu^{\prime}=\tan \phi^{\prime}$ を 用いる。吊は土の内部摩擦角を表わす。

埋設管の土被りが深い場合には鉛直せん断面は地表ま で到達せず, 等沈下面とよばれるある高さの位置でとよ゙ まる．この状態が不完全突出条件であり，土被り圧で正 規化した土圧は

$$
\begin{aligned}
\frac{\sigma_{v}^{\prime}}{\gamma H}= & \frac{B_{c}}{H}\left\{\frac{\exp \left(2 K \mu^{\prime} \cdot H_{e} / B_{c}\right)-1}{2 K \mu^{\prime}}\right. \\
& \left.+\left(\frac{H}{B_{c}}-\frac{H_{e}}{B_{c}}\right) \exp \left(2 K \mu^{\prime} \cdot H_{e} / B_{c}\right)\right\} .
\end{aligned}
$$

で表わされる.ここに， $H_{e}$ : 等沈下面の高さ，であり 他の記号は式 $(1)$ と同じである. $H_{e}$ は

$$
\left\{\frac{1}{2 K \mu^{\prime}}+\left(\frac{H}{B_{c}}-\frac{H_{e}}{B_{c}}\right)+\frac{\gamma_{s d} p}{3}\right\} \frac{\exp \left(2 K \mu^{\prime} \cdot H_{e} / B_{c}\right)-1}{2 K \mu^{\prime}}
$$

$$
\begin{aligned}
& +\frac{1}{2}\left(\frac{H_{e}}{B_{c}}\right)^{2}+\frac{\gamma_{s d} p}{3}\left(\frac{H}{B_{c}}-\frac{H_{e}}{B_{c}}\right) \exp \left(2 K \mu^{\prime} \cdot H_{e} / B_{c}\right) \\
& -\frac{1}{2 K \mu^{\prime}} \cdot \frac{H_{e}}{B_{c}}-\frac{H \cdot H_{e}}{B_{c}^{2}}=\gamma_{s d} p \cdot \frac{H}{B_{c}} \ldots \ldots \ldots \ldots \ldots \ldots . \cdots(3)
\end{aligned}
$$

を解くことにより求められる.ここに, $\gamma_{s d}$ : 沈下比, $p$ : 突出比,である.

\section{（2）Meyerhof-Adams の土圧算定式}

Meyerhof-Adams ${ }^{8)}$ は連続基礎の引き抜き抵抗力を土 被りが浅い場合と深い場合に分けて提案した. 基礎が周 辺地盤に対して突出することにより引き抜き抵抗力が生 じる，という点で引き抜き抵抗力の問題は突出条件下の 埋設管に作用する土圧の問題と同じである.したがって, 基礎の形状を円管に変えることにより彼らの提案した算 定式を埋設管の問題に適用できる.

彼らは基礎を上方に引き抜くときに地中に生じるすべ り面を鉛直に仮定し，引き抜き抵抗力を求めた．鈶直す ベり面は基礎の端より上方に伸び，土被りが浅い場合に は地表まで到達する，基礎の形状を円管に変えること， および, 鉛直すべり面は管の側部より上方に伸びること, の 2 点を変更し, その他は彼らの計算方法に従って埋設 管に作用する土圧を計算すると，土被りの浅い場合の土 圧は

$$
\begin{aligned}
& \frac{\sigma_{v}^{\prime}}{\gamma H}=\frac{\left(H+B_{c} / 2\right)^{2}}{H B_{c}} K \tan \phi^{\prime}+\frac{H+B_{c} / 2}{H B_{c}} \cdot \frac{2 c^{\prime}}{\gamma} \\
& +\frac{H+(1 / 2-\pi / 8) B_{c}}{H}
\end{aligned}
$$

になる、ここに， $c^{\prime}$ ：土の粘着力，であり，その他の記 号は式（1）と同じである. 彼らは $K$ の値として, $K$ $=0.95$ を推奖した.

次に，土被りが深い場合には鉛直すべり面は地表まで 到達せず，途中でとどまると彼らは仮定した．この場合 について土被りが浅い場合と同様にして埋設管に作用す る土圧を計算すると

$$
\begin{aligned}
\frac{\sigma_{v}^{\prime}}{\gamma H}= & \frac{\left(2 H-H_{e}+B_{c} / 2\right)\left(H_{e}+B_{c} / 2\right)}{H B_{c}} K \tan \phi^{\prime} \\
& +\frac{H_{e}+B_{c} / 2}{H B_{c}} \cdot \frac{2 c^{\prime}}{\gamma}+\frac{H+(1 / 2-\pi / 8) B_{c}}{H} \cdots
\end{aligned}
$$

になる．ここに, $H_{e}$ ：管頂から鉛直すべり面の上端ま での距離であり，実験結果に基づいて彼らはTable 1 の值を推奖した. $K$ の值は式 $(4)$ と同じく 0.95 であ る.

なお，Marston-Spangler と Meyerhof-Adams は同じ 鉛直すべり面（Marston-Spangler はすべり面とはよん でいないが，実質的にはすべり面のように扱っている)

Table 1 Magnitude of $H_{e}^{8)}$.

\begin{tabular}{|c|c|c|c|c|c|c|c|}
\hline$\phi^{\prime}$ & $20^{\circ}$ & $25^{\circ}$ & $30^{\circ}$ & $35^{\circ}$ & $40^{\circ}$ & $45^{\circ}$ & $48^{\circ}$ \\
\hline$\left(\mathrm{He}+\frac{8 \mathrm{C}}{2}\right) / \mathrm{Bc}$ & 2.5 & 3 & 4 & 5 & 7 & 9 & 11 \\
\hline
\end{tabular}


を仮定しているにもかかわらず算定式の形が異なってい る.これは鉛直すべり面に作用する摩擦力（せん断抵抗 力）の計算方法などが異なるためである.この点につい ては以下に引き続いて示す他の算定式と合わせて，（6 ) でまとめて対比する.

\section{(3) Trautmann らの土圧算定式}

Trautmann ら ${ }^{9)}$ は突出条件下の埋設管に作用する土圧 の研究で, 式 (4) における土圧係数 $K$ の值は締め固 めの程度によって変化すると考え，ゆるい砂では 0.50 , 中密度の砂では 0.65 , 高密度の砂では 0.75 とすると実 験結果とよく一致することを報告した．彼らの研究では 土の粘着力は考慮されていない，また，鈶直すべり面は 途中でとゼまることはなく，地表面まで到達すると仮定 している. したがって埋設管に作用する土圧の算定式は

$$
\frac{\sigma_{v}^{\prime}}{\gamma H}=\frac{\left(H+B_{c} / 2\right)^{2}}{H B_{c}} K \tan \phi^{\prime}+\frac{H+(1 / 2-\pi / 8) B_{c}}{H}
$$

になる. $K$ の值は, $K=0.50$ (ゆるい砂), $K=0.65$ (中 密度の砂), $K=0.75$ (高密度の砂)，である.

\section{(4) Ladanyi-Hoyaux の土圧算定式}

Ladanyi-Hoyaux ${ }^{10)}$ は砂中に埋め込まれた平板を上 昇，下降させたときに平板に作用する土圧の算定式を提 案した．突出条件下の埋設管に作用する土圧は平板を上 昇させたときに平板に作用する土圧に相当するので，平 板を円管に変えることによりこの場合の土圧算定式を埋 設管に適用できる。

彼らもすべり面については平板の端より上方に伸び, 地表面まで達する鉛直すべり面を仮定した。また，土の 粘着力は考慮していない，平板を円管に変えること，お よび鉛直すべり面は管の側部より上方に伸びること，の 2 点のみを変更し，その他は彼らの計算方法に従って土 圧を計算すると，式（6）と同じ式が得られる．ただし， 土圧係数 $K$ の值は異なっている. 彼らは $K$ の値として クーロンの受働土圧係数である $K=\cos ^{2} \phi^{\prime}$ を用いた。

\section{（5） 円弧すべり面モデルの土圧算定式}

松尾 ${ }^{11}$ は対数らせんと直線を組み合わせたすべり面を 仮定し，このすべり面に Kötter の方程式を適用して基 礎の引き抜き抵抗を算定した。 また勝見・西原 ${ }^{12}$ は円弧 すべり面を仮定し，松尾と同じ手法を用いて基礎の引き 抜き抵抗を算定した。そこで著者らはこの手法を突出条 件下の埋設管に作用する土圧の問題に適用し，土圧の算 定を試みた。松尾, 勝見らとの相違点は, 彼らが軸対称 問題を扱っているのに対し，著者らが二次元問題を扱っ ている点にある．すべり面の形状については著者らは勝 見らと同じく円弧すべり面を仮定した。これは次章に述 べる実験や高木ら ${ }^{4)}$ の室内実験で得られたすべり面を観 察した結果, 対数らせんと直線を組み合わせたすべり面

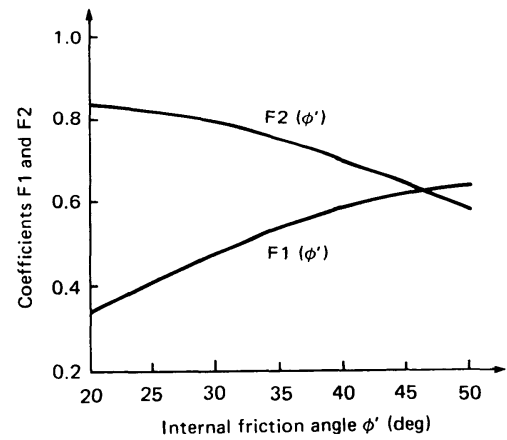

Fig. 1 Coefficients $F_{1}$ and $F_{2}$ in Circular Slip Surface Model.

よりも円弧すべり面の方が実際のすべり面をよく近似で きることがわかったためである。

一方, Vesić(1), 14) は地中に埋設された円筒状の物体を 引き抜くときの抵抗力を剛塑性体中の表面近くにある円 筒を膨張させる問題として解析し，土被り/口径が 4.5 以下のときの抵抗力を数表で示した．文献 13）には数 表のみが示されており，詳しい解析方法は文献 14）に 述べられていると思われるが，この文献はアメリカ陸軍 に提出された報告書で，入手が困難であり，現在までに 手に入っていない。しかし，数表の値を著者らの方法に よる土圧算定値と比較してみたところ，完璧に一致して いることがわかった，そのためVesić の土圧算定式も 著者らと同じ方法で求められたと推察している.

円弧すべり面を仮定して Kötter の方程式を解き，埋 設管に作用する土圧を算定する方法は Appendixに示し た。結果のみを示すと,

$$
\begin{aligned}
& \frac{\sigma_{v}^{\prime}}{\gamma H}=\frac{\left(H+B_{c} / 2\right)^{2}}{H B_{c}} F_{1}\left(\phi^{\prime}\right)+\frac{H+B_{c} / 2}{H B_{c}} \cdot \frac{2 c^{\prime}}{\gamma} F_{2}\left(\phi^{\prime}\right) \\
& +\frac{H+(1 / 2-\pi / 8) B_{c}}{H}
\end{aligned}
$$

である．ここに $F_{1}\left(\phi^{\prime}\right), F_{2}\left(\phi^{\prime}\right)$ は土の内部摩擦角より決 まる定数で, Fig. 1 より求める.

（6）各土圧算定式における解析方法の相違点

Table 2 に各土圧算定式における解析上の仮定を一覧 表にしてまとめた．各算定式は鉛直すべり面を仮定する か，円弧すべり面を仮定するか，によって大きく2つに 分類される．鉛直すべり面を仮定する場合には，Fig. 2 に示すように微小部分の力のつり合いを考えた微分方程 式を解くか，あるいはすべり面に作用する摩擦力の総和 を計算し，これにすべり面に聿まれる領域の土の重量を 加える方法により土圷算定式を導いている．各算定式の 相違点は 1 つには Table 2 に示したように土圧係数 $K$ の値から生じている． Marston-Spangler 式ではランキ ンの主働土圧係数, Meyerhof-Adams 式, Trautmann らの算定式では経験的に定めた值，Ladanyi-Hoyaux 式 
Table 2 Assumptions in Various Formulas.

\begin{tabular}{|c|c|c|c|c|c|c|}
\hline $\begin{array}{c}\text { Reported } \\
\text { by }\end{array}$ & $\begin{array}{l}\text { Assumed } \\
\text { slip surface }\end{array}$ & $\begin{array}{l}\text { Coefficient } \\
\text { of horizontal } \\
\text { stress (K) }\end{array}$ & $\begin{array}{l}\text { Horizontal } \\
\text { stress } \\
\left(\sigma^{\prime}\right)\end{array}$ & $\begin{array}{c}\text { Coefficient } \\
\text { of friction } \\
\left(\mu^{\prime}\right)\end{array}$ & Cohesion & $\begin{array}{l}\text { Incomplete } \\
\text { projection } \\
\text { condition }\end{array}$ \\
\hline $\begin{array}{l}\text { Marston- } \\
\text { Spangler }\end{array}$ & Vertical & $\frac{1-\sin \phi^{\prime}}{1+\sin \phi^{\prime}}$ & $\mathrm{K} \sigma_{\dot{v}}^{\prime}$ & $\tan \phi^{\prime}$ & $\begin{array}{l}\text { Not } \\
\text { considered }\end{array}$ & Considered \\
\hline $\begin{array}{l}\text { Meyerhof- } \\
\text { Adams }\end{array}$ & Vertical & 0.95 & $(\mathrm{~K} \gamma \mathrm{z})$ & $\tan \phi^{\prime}$ & Considered & Considered \\
\hline $\begin{array}{l}\text { Trautmann } \\
\text { et al. }\end{array}$ & Vertical & $\begin{array}{l}0.50 \text { (loose) } \\
0.65 \text { (medium) } \\
0.75 \text { (dense) }\end{array}$ & $K \gamma z$ & $\tan \phi^{\prime}$ & $\begin{array}{l}\text { Not } \\
\text { considered }\end{array}$ & $\begin{array}{l}\text { Not } \\
\text { considered }\end{array}$ \\
\hline $\begin{array}{l}\text { Ladanyi- } \\
\text { Hoyaux }\end{array}$ & Vertical & $\cos ^{2} \phi^{\prime}$ & $\mathrm{K} \gamma z$ & $\tan \phi^{\prime}$ & $\begin{array}{l}\text { Not } \\
\text { considered }\end{array}$ & $\begin{array}{l}\text { Not } \\
\text { considered }\end{array}$ \\
\hline $\begin{array}{l}\text { Authors } \\
\text { (Vesić) }\end{array}$ & Circular & \multicolumn{3}{|c|}{ Kötter's equation } & Considered & $\begin{array}{l}\text { Not } \\
\text { considered }\end{array}$ \\
\hline
\end{tabular}

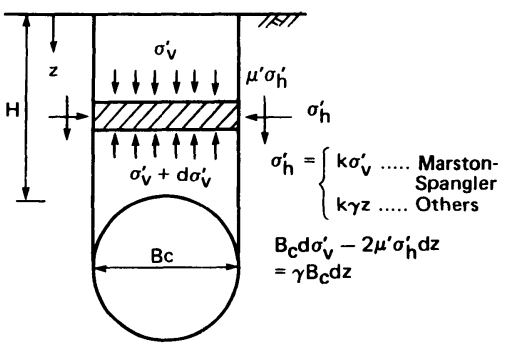

Fig. 2 Vertical Slip Surface Model.

ではクーロンの受働土王係数をそれぞれ用いている。 ま た, 水平応力の求め方にも相違点がある. MarstonSpangler 式では水平応力がすべり面の内側の鉛直応力 に比例するものとしている.このため, 結果に指数関数 の項が生じ，他とは形の異なる算定式になっている．一 方, Trautmann らおよび Ladanyi-Hoyaux はすべり面 の外側の鉛值応力が $\gamma z$ で表わされること，そして，水 平応力が $\gamma z$ に比例することを仮定している．また， Meyerhof-Adams はすべり面に作用する全摩擦力を求 めており, 水平忘力や摩擦力の深さ方向の分布について の記述はみられないが, 全摩擦力が $1 / 2 \gamma z^{2}$ に比例する 形になっていることから Trautmann らと同系統に属す ると考えられる.摩擦係数の值はいずれの式でも同じで ある.このほかにも土の粘着力の考虑の有無, 不完全突 出条件の考慮の有無（すべり面が地表まで到達するか否 か）についても各算定式には差がある.

\section{3. 実験による土圧の測定}

\section{（1）実験の種類}

突出条件下の埋設管に作用する土圧の実験を中口径管 の実験と加室らの小口径管の実験 ${ }^{5)} に$ 分けて述べる．前 者は，土圧の測定と地中に生じるすべり面の観察を目的 とした実験で，円弧すべり面モデルによる土圧算定式を 導く過程で行った，後者は，著者らの所属する研究所で 15 年ほど以前に行われた実験であるが，次章で円弧す
ベり面モデルをはじめとする各土王算定式を検討する際 に有用な実験データとなるので，本章で実験内容に触れ ておく.

\section{（2）中口径管の実験}

a) 実験装置および方法

Fig. 3 に実験装置を示す。この実験では実験槽の床面 に穴を開け，槽の下側の基礎部分から支柱を立てた。そ して，支柱の間にH鋼を渡し，H鋼の上にかぶせるよう にして供試管を設置した. そのため，管の下端は開いた 形状になっている(Fig. 3(a)). 供試管は 3 分割し，そ れぞれの管とH鋼との間にロードセルを入れて管に作用 する土环を測定した。管の端面はアクリル板でふたをし た.また，管の端面と端面の間，および管の下端の開い た部分と内側の $\mathrm{H}$ 鋼との間にはウレタンフォーム材を詰 めた．供試管の口径は Table 3 に示す 3 種類で，外面を プラスチックライニングされた鋼管を用いた。埋め戻し は山砂で行い, $30 \mathrm{~cm}$ ごとに均等に転圧した。このとき， 土槽中央で管軸と直角方向に石灰を $2 \mathrm{~cm}$ ほどの厚さで 撤いておき，実験終了後に掘削して石灰層に生じた段差 の位置からすべり面の位置を観察した。供試管の土被り は $1.2 \mathrm{~m}$ とした.

埋め戻し終了後に支柱の下端に挿入した手動のジャッ キで埋設管を均等に押し上げながら管に作用する土圧を 测定した。

\section{b）埋め戻し土の土質特性}

埋め戻しに用いた山砂の土質特性を Table 4 に示す. $\phi^{\prime}$ は埋め戻した状態での含水比 $(11 \sim 14 \%)$, 湿潤単位 体積重量 $\left(15.6 \sim 16.2 \mathrm{kN} / \mathrm{m}^{3}\right)$ とほぼ等しくなるよう に調整した試料による CD 試験の $\phi_{d}$ で代用した。 $c^{\prime}$ は ゼロとみなした。また，埋め戻した状態での相対密度は

Table 3 Dimensions of Pipes.

\begin{tabular}{|l|c|c|c|}
\hline Nominal diameter $(\mathrm{mm})$ & 200 & 400 & 600 \\
\hline Outside diameter $(\mathrm{mm})$ & 216.3 & 406.4 & 609.6 \\
\hline Inside diameter $(\mathrm{mm})$ & 204.7 & 390.6 & 590.6 \\
\hline
\end{tabular}




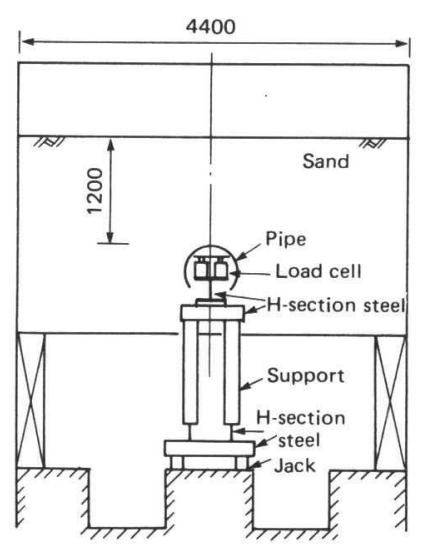

(a) Front view

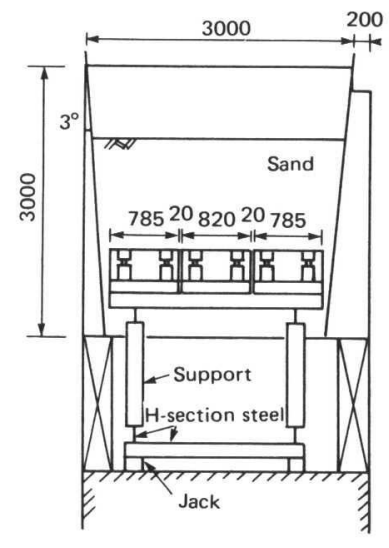

(b) Profile view

Fig. 3 Apparatus Used in Experiment.

Table 4 Properties of Soil.

\begin{tabular}{|c|c|c|c|c|c|}
\hline$G_{s}$ & $\begin{array}{c}\text { Gravel } \\
(\%)\end{array}$ & $\begin{array}{c}\text { Sand } \\
(\%)\end{array}$ & $\begin{array}{c}\text { Silt } \\
(\%)\end{array}$ & $\begin{array}{c}\text { Clay } \\
(\%)\end{array}$ & $U_{\mathrm{c}}$ \\
\hline 2.69 & 0.0 & 94.0 & 6.0 & 0.0 & 2.3 \\
\hline $\mathrm{U}_{\mathrm{c}^{\prime}}$ & $\begin{array}{c}\gamma_{\mathrm{dmax}} \\
\left(\mathrm{KN} / \mathrm{m}^{3}\right)\end{array}$ & $\begin{array}{c}\gamma_{\mathrm{dmin}} \\
\left(\mathrm{KN} / \mathrm{m}^{3}\right)\end{array}$ & $\begin{array}{c}\mathrm{W}_{\text {opt }} \\
(\%)\end{array}$ & $\phi^{\prime}$ & $\begin{array}{c}\mathrm{c}^{\prime} \\
\left(\mathrm{KN} / \mathrm{m}^{2}\right)\end{array}$ \\
\hline 1.3 & 17.1 & 11.4 & 12 & $36^{\circ}$ & $\approx 0.0$ \\
\hline
\end{tabular}

平均で 0.59 であった.

c) 土圧の測定結果

この実験では手動ジャッキによる管の押し上げと土圧 の測定を繰り返しながら実験を進めた。最大押し上げ量 は $10 \mathrm{~cm}$ で,ほぼ $1 \mathrm{~mm}$ 押し上げるごとに土圧を測定し た.

3 分割された供試管の土圧測定結果は, 中央の管に比 べて端部の管で大きな値を示した。これは管端面と実験 槽壁面との間の摩擦力のためと考えられたので, 土圧の 解析には中央の管で測定された土王を用いた。 中央の管 で測定された土圧を押し上げ量との関係として Fig. 4 に 示す.また，土圧の最大値と垂直土圧の比も示す.

d）地表面の変化とすべり面の位置

Photo 1 は口径 $600 \mathrm{~mm}$ の実験で管を $10 \mathrm{~cm}$ 押し上げ た状態での写真である，管はクラックのほぼ真下に埋設 されている. また，クラックに直交する球の列は間隔が $20 \mathrm{~cm}$ である.

管を地中で押し上げていくと，押し上げ量が $0.5 \sim 2$ $\mathrm{cm}$ のときに管の直上にクラックが生じ始めた.このク ラックは押し上げを続けるにつれて数が増し, 幅も広 がった.また，押し上げ量が3〜8.5 cmに達したとき に写真の手前にみえる段差が地表面に現われ始めた.こ の段差も押し上げを続けるにつれてしだいに明確になっ てきた. 段差の内側では地表面が盛り上がり，外側では 静止していることから，この段差の位置が地表面でのす

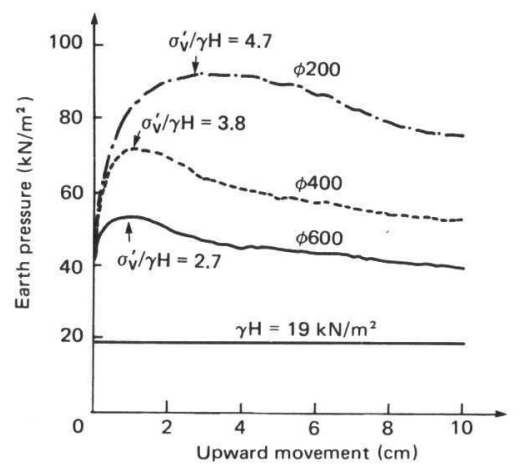

Fig. 4 Earth Pressure vs. Upward Movement. 

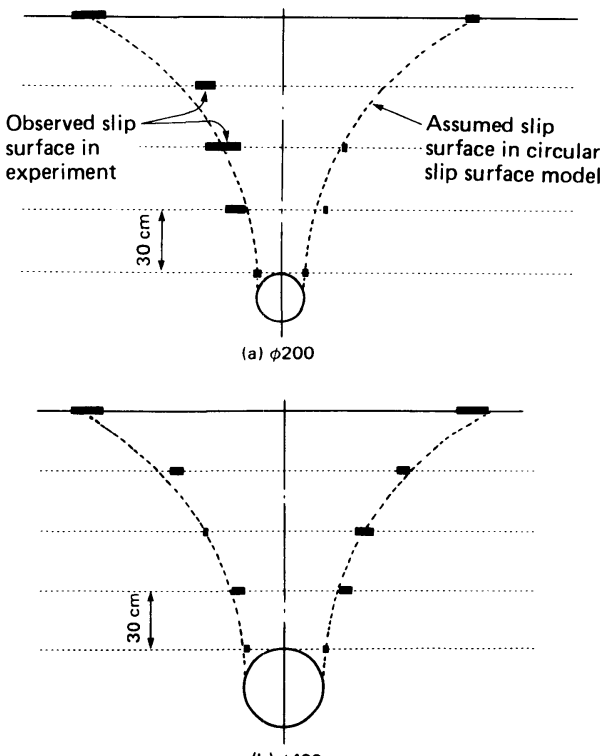

(b) $\varnothing 400$

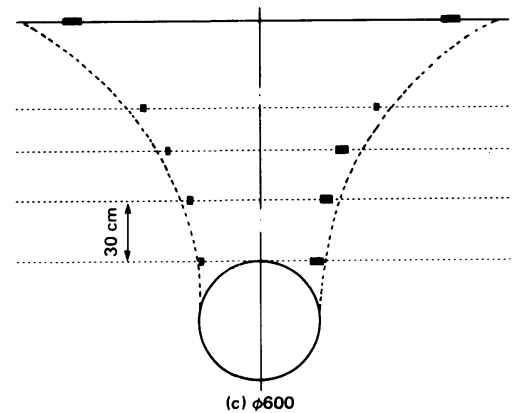

Fig. 5 Observed Slip Surfaces in Experiments and Assumed Slip Surfaces in Circular Slip Surface Model.

うな地表面および石灰層の段差から観察されたすべり面 の位置と円弧すべり面を仮定する土圧算定法で解析に用 いた円弧すべり面の位置 (Appendix に示したように, 土の内部摩擦角から形状が決まる）を示している. 2. で述べたように，多くの土王算定式では鉛直すべり面を 仮定している.しかし，実験で観察されたすべり面は鉛

直すべり面よりも円弧すべり面でよく近似できることが この図より明らかである. また，土圧のピーク時をせん 断のピーク時と考えると土圧のピーク時にはすべり面は まだ生じていないと考えられる.しかし，X線を用いて 砂中に埋め込まれた鉛玉の動きを追跡する室内実験によ ると, 大きなせん断ひずみが生じる位置と後にX線写真 に撮影されるすべり面の位置はほぼ等しい4). したがっ て, 土圧のピーク時に Fig. 5 に示した位置でせん断ひず みが卓越していたと考えてよいであろう.

（3）加室らの実験)

a) 実験装置および方法

Fig. 6 に実験装置を示す. 実験槽の中に支柱を立て, 間にロードセルを介して枕木を置き,供試管を設置した. 供試管の口径は Table 5 に示す 4 種類で, 外面をプラス チックライニングされた鋼管を用いた。 実験槽の下部に

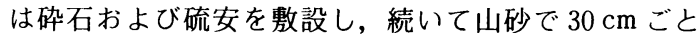
に転圧しながら埋め戻した。管の土被りは $1.5 \mathrm{~m}$ とし た。

埋め戻し終了後に地盤を強制的に沈下させて供試管に 作用する土圧をロードセルで測定した．地盤の沈下は実 験槽下部に注水し, 硫安層を水で溶解させることにより 生じさせた。

\section{b）埋め戻し土の土質特性}

埋め戻しに用いた山砂の土質特性を Table 6 に示す。 埋め戻した状態での湿潤単位体積重量は $15.7 \sim 16.3$ $\mathrm{kN} / \mathrm{m}^{3}$, 含水比は $5 \sim 8 \%$ であった. なお, 砂の力学試 験は CD 試験と思われるが, その結果を代用して $\phi^{\prime}$ と した. $c^{\prime}$ はゼロと考えた. また，表に示した以外の土 質特性は明らかでないが, 通常の埋設管の埋め戻し工法 が採られていることから, 相対密度も先の中口径管の実 験と同じく 0.6 前後と推定される.

Table 5 Dimensions of Pipes.

\begin{tabular}{|l|c|c|c|c|}
\hline Nominal diameter $(\mathrm{mm})$ & 80 & 100 & 150 & 200 \\
\hline Outside diameter $(\mathrm{mm})$ & 89.1 & 114.3 & 165.2 & 216.3 \\
\hline Inside diameter $(\mathrm{mm})$ & 80.7 & 105.3 & 155.2 & 204.7 \\
\hline
\end{tabular}

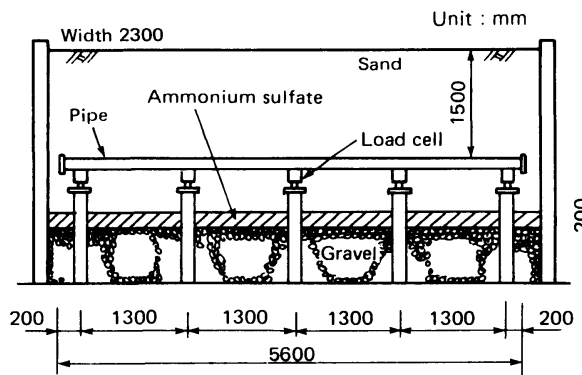

(a) Profile view

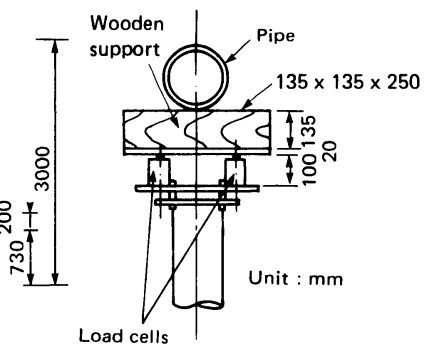
(b) Detail of pipe supporting

Fig. 6 Apparatus Used in Experiment. 
Table 6 Properties of Soil.

\begin{tabular}{|c|c|c|c|c|c|c|}
\hline $\begin{array}{c}\text { Nominal } \\
\text { diameter }\end{array}$ & $\begin{array}{c}\text { Gravel } \\
(\%)\end{array}$ & $\begin{array}{c}\text { Sand } \\
(\%)\end{array}$ & $\begin{array}{c}\text { Silt } \\
(\%)\end{array}$ & $\begin{array}{c}\text { Clay } \\
(\%)\end{array}$ & $\phi^{\prime}$ & $\begin{array}{c}\mathrm{C}^{\prime} \\
\left(\mathrm{KN} / \mathrm{m}^{2}\right)\end{array}$ \\
\hline 80,150 & 21.1 & 78.5 & 0.4 & 0.0 & $40^{\circ}$ & $\approx 0.0$ \\
\hline 100 & 2.5 & 85.0 & 12.5 & 0.0 & $38^{\circ}$ & $\approx 0.0$ \\
\hline 200 & 2.5 & 89.6 & 7.9 & 0.0 & $35^{\circ}$ & $\approx 0.0$ \\
\hline
\end{tabular}

Table 7 Observed Earth Pressures.

\begin{tabular}{|c|c|c|}
\hline $\begin{array}{c}\text { Nominal } \\
\text { diameter }\end{array}$ & $\begin{array}{c}\text { Earth pressure } \\
\sigma_{\mathrm{v}}^{\prime}\left(\mathrm{kN} / \mathrm{m}^{2}\right)\end{array}$ & $\begin{array}{c}\text { Normalized earth } \\
\text { pressure } \sigma_{\mathrm{v}}^{\prime} / \gamma \mathrm{H}\end{array}$ \\
\hline 80 & 200 & 8.4 \\
\hline 100 & 211 & 9.0 \\
\hline 150 & 146 & 6.0 \\
\hline 200 & 125 & 5.3 \\
\hline
\end{tabular}

\section{c）土圧の測定結果}

この実験では動的ひずみ計測器で沈下時の土圧が測定 された．土圧の最大値を Table 7 に示す．なお，地盤の 沈下量は測定されていないので, 土圧と沈下量の関係は 明らかでない，また，枕木の存在により土圧は大きめに 測定されている.この影響は $5 \%$ 前後と推定されるが, 管の口径によっても異なり, 正確な見積りが難しいので, 表には測定された值をそのまま示した。

\section{4. 実験結果と各土圧算定式との比較}

実験により測定された土圧と各土圧算定式により計算 された土圧の比較を Fig. 7 に示す. 土圧の計算にあたつ て土の単位体積重量および内部摩擦角の值にはすべての 実験での平均値である $\gamma=15.9 \mathrm{kN} / \mathrm{m}^{3}, \phi^{\prime}=37^{\circ}$ を用い た.また, Trautmann らの算定式の土圧係数には中密 の値 $K=0.65$ を用いた.

図より明らかなように Marston-Spangler の完全突出 条件による土圧は土被り/口径が大きいときにはかなり 過大であり，小さいときには過小に評価している.一方，

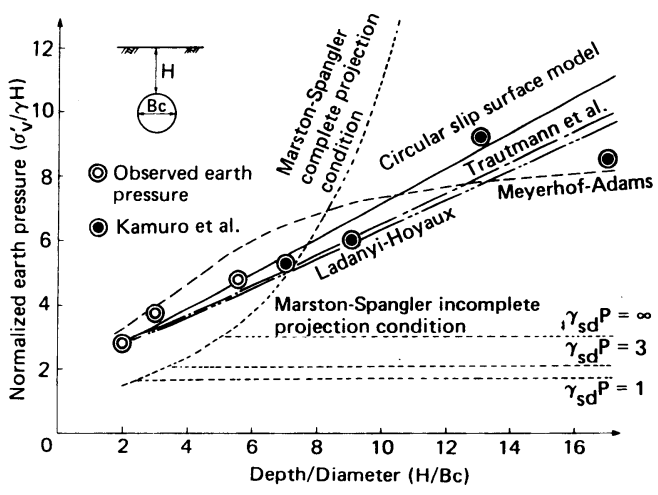

Fig. 7 Comparison of Observed Earth Pressures with Estimated Ones.
不完全突出条件を用いると計算された土圧は実験值より もかなり小さい，したがって，Marston-Spangler の土 圧算定式では実験結果を説明できない。次に， Meyerhof-Adams の算定式は土被り/口径が小さいとき にやや過大であり，大きいときにやや過小である．その 他の円弧すべり面モデル，Trautmann ら，LadanyiHoyaux の 3 つの算定式には大きな差はない．加室らの 実験での真の土圧は図の值よりもやや小さいと考えられ るが，これを考慮してもこれらの 3 式による計算値はい ずれも実験値とほぼ一致している，しかし，Trautmann らや Ladanyi-Hoyaux は実際にみられるものとは異な る鉛直すべり面を仮定しており，モデルの厳密性からは 円弧すべり面モデルの方がすぐれていると考えられる． したがって，突出条件下の埋設管に作用する土圧の算定 には円弧すべり面モデルによる土圧算定式が最も適切と 考える.

\section{5. 結 論}

（1） Marston-Spangler の突出条件土圧算定式では 完全突出条件, 不完全突出条件のいずれを用いても実験 により測定された土圧を説明できない.

（2）円弧すべり面モデル, Trautmann ら, LadanyiHoyaux の 3 つの算定式には大きな差はなく，いずれも 実験により測定された土圧とほぼ一致した。

（3）実験で観察されたすべり面は円弧に近い。この 点から，円弧すべり面モデルによる計算が最も妥当と考 えられる.

以上のように, Marston-Spangler の算定式が実験と 合わず，これまでに仮定の不合理性を指摘してきた多く の批判が正しいことが確認された。 それに代わって, 円 弧すべり面を仮定したKötter の方程式に基づく算定式 を示した. 今後, これによって従来の Marston-Spangler 理論による設計の体系が修正されることを期待する.

なお，本論文の実験では実際の埋設管工事と同じ方法 で埋め戻しており，この意味では現場への適用性が高い と考えられる. しかし，仮にゆるく埋め戻した場合には すべり面の形状や土圧の值が異なってくるであろう．事 実,ゆるい埋め戻しの場合には管の周辺ですべり面が消 堿することが室内実験で観察されている4).また，土被 り/口径が大きくなると，すべり面は地表まで到達せず， 不完全突出状態になると考えられる．これらの条件での 土圧の解析や不完全突出に移行する土被り/口径の值に ついては今後の研究課題と考えている.

\section{Appendix 円弧すべり面モデルによる土圧の 計算}

（1）すべり面の形状 
すべり面は管の側部で管と接し，地表面と $\pi / 4-\phi^{\prime} / 2$ ( $\phi^{\prime}$ : 土の内部摩擦角) で交わる円弧により近似できる と仮定する.これらの仮定によりすべり面の形状が Fig. A.1 に示すように定まる. 円弧の中心は管の中心と 同じ深さにあり, その半径 $R$ は

$$
R=\frac{H+B_{c} / 2}{\sin \left(\pi / 4+\phi^{\prime} / 2\right)}
$$

である。

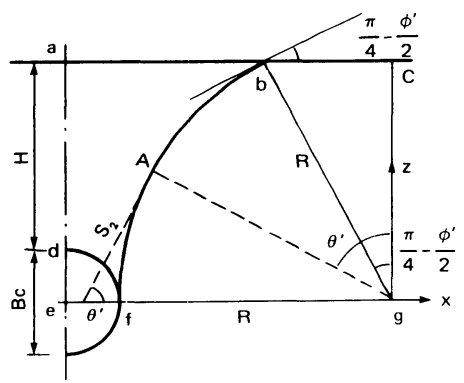

Fig. A.1 Circular Slip Surface.

\section{（2）円弧すべり面に囲まれる領域の土の重田}

埋設管の単位長さを考えて，円弧すべり面に井まれる 領域の重量を計算する. Fig. A·1 を参考にして $(a b \cdots)$ でその領域の面積を表わすと, 土の重量 $W$ は

$$
\begin{aligned}
W= & 2 \gamma(a d f b)=2 \gamma\{(\text { aegc })-(b g c)-(b f g)-(\text { def })\} \\
= & 2 \gamma\left\{\left(H+\frac{B_{c}}{2}\right)\left(R+\frac{B_{c}}{2}\right)-\frac{1}{2} R\left(H+\frac{B_{c}}{2}\right)\right. \\
& \left.\times \cos \left(\frac{\pi}{4}+\frac{\phi^{\prime}}{2}\right)-\frac{1}{2} R^{2}\left(\frac{\pi}{4}+\frac{\phi^{\prime}}{2}\right)-\frac{\pi}{16} B_{c}^{2}\right\}
\end{aligned}
$$

になる， $\gamma$ は土の単位体積重量を表わす。

\section{（3）円弧すべり面に作用する鉛直方向の力}

円弧すべり面に作用する鉛直方向の力はこのすべり面 に次式で表わされる Kötter の方程式 ${ }^{15)}$ を適用して計算 する.

$$
\begin{array}{cr}
\cos \phi^{\prime} \frac{d \sigma_{m}^{\prime}}{d s_{1}}-2\left(\sigma_{m}^{\prime} \sin \phi^{\prime}+c^{\prime} \cos \phi^{\prime}\right) \frac{d \theta}{d s_{1}} \\
=\gamma \sin \left(\theta-\phi^{\prime}\right) & (\text { i }) \\
\cos \phi^{\prime} \frac{d \sigma_{m}^{\prime}}{d s_{2}}+2\left(\sigma_{m}^{\prime} \sin \phi^{\prime}+c^{\prime} \cos \phi^{\prime}\right) \frac{d \theta}{d s_{2}} \\
=\gamma \cos \theta
\end{array}
$$

ここで, $\sigma_{m}^{\prime}=\left(\sigma_{1}^{\prime}+\sigma_{3}^{\prime}\right) / 2$ : 平均主応力 $\left(\sigma_{1}^{\prime}, \sigma_{3}^{\prime}\right.$ は最大, 最小主応力), $s_{1}$ および $s_{2}$ : 最大主応力と $\pi / 4-\phi^{\prime} / 2$ の角度で交差する 2 つのすべり面 (Fig. A.2参照), $\theta$ $: s_{1}$ すべり面が $x$ 軸と交わる角度 (Fig. A.2 参照), で ある。

さて, 円弧すべり面に作用する最大主応力 $\sigma_{1}^{\prime}$ の方向

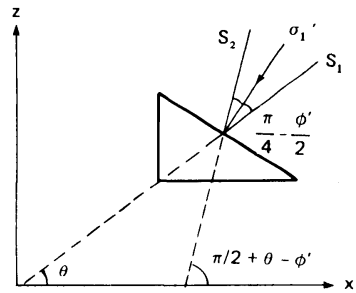

Fig. A.2 Direction of Slip Surface.

を考えると, 円弧すべり面は最大主忘力の方向から反時 計回りに $\pi / 4-\phi^{\prime} / 2$ の角度で回転したすべり面，すな わち,Fig.A·2 における $s_{2}$ すべり面である.したがって， 式 $(\mathrm{A} \cdot 3)$ の（ii）を円弧すべり面に適用すればよい.

ここで, Fig. A·1に示したように， $z$ 軸から円弧上の

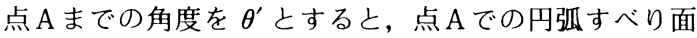
の接線 $s_{2}$ は $x$ 軸と $\theta^{\prime}$ で交わる. したがって, Fig. A·2 より

$$
\theta^{\prime}=\pi / 2+\theta-\phi^{\prime}
$$

すなわち

$$
\theta=-\pi / 2+\theta^{\prime}+\phi^{\prime}
$$

である.また，

$$
d s_{2}=R d \theta^{\prime}
$$

なので,

$$
\frac{d \theta}{d s_{2}}=\frac{d \theta^{\prime}}{d s_{2}}=\frac{1}{R}
$$

$$
\cos \phi^{\prime} \frac{d \sigma_{m}^{\prime}}{d s_{2}}=\frac{\cos \phi^{\prime}}{R} \cdot \frac{d \sigma_{m}^{\prime}}{d \theta^{\prime}}
$$

が成り立つ.これらの式 $(\mathrm{A} \cdot 4) \sim(\mathrm{A} \cdot 6)$ を式 $(\mathrm{A} \cdot 3)$ の（ii）に代入して整理すると，微分方程式

$$
\frac{d \sigma_{m}^{\prime}}{d \theta^{\prime}}+2 \tan \phi^{\prime} \sigma_{m}^{\prime}=\gamma R \frac{\sin \left(\theta^{\prime}+\phi^{\prime}\right)}{\cos \phi^{\prime}}
$$

が得られる.

地表面 $\left(\theta^{\prime}=\pi / 4-\phi^{\prime} / 2\right)$ での $\sigma_{m}^{\prime}$ は Fig. A.3を参照 して幾何学的関係を調べると

$$
\sigma_{m}^{\prime}=\frac{c^{\prime} \cos \phi^{\prime}}{1-\sin \phi^{\prime}}
$$

になる.この境界条件で式 $(\mathrm{A} \cdot 7)$ を解くと，

$$
\sigma_{m}^{\prime}=\frac{\gamma R}{\cos \phi^{\prime}\left(4 \tan ^{2} \phi^{\prime}+1\right)}\left[2 \tan \phi^{\prime} \sin \left(\theta^{\prime}+\phi^{\prime}\right)\right.
$$

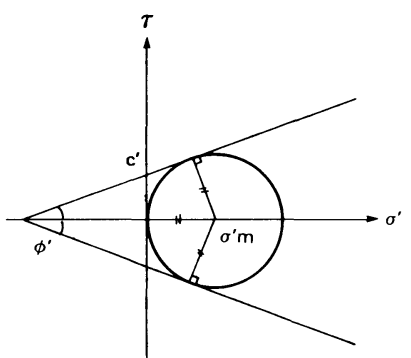

Fig. A.3 Mohr's Circle at Surface. 


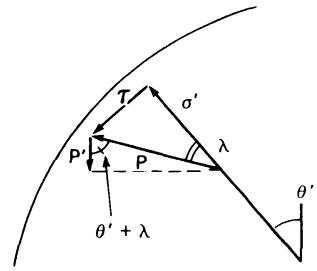

Fig. A-4 Resultant Shearing Resistance $p$ on the Slip Surface.

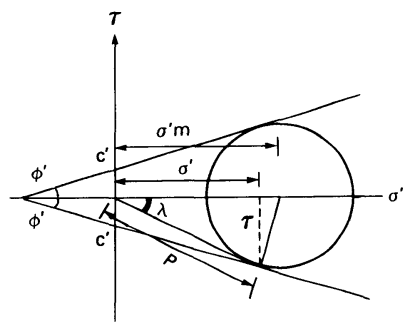

Fig. A.5 Resultant Shearing Resistance $p$ in Mohr's Circle.

$$
\begin{aligned}
& -\cos \left(\theta^{\prime}+\phi^{\prime}\right)-\left\{2 \tan \phi^{\prime} \sin \left(\frac{\pi}{4}+\frac{\phi^{\prime}}{2}\right)\right. \\
& \left.\left.-\cos \left(\frac{\pi}{4}+\frac{\phi^{\prime}}{2}\right)\right\} \exp \left\{2\left(\frac{\pi}{4}-\frac{\phi^{\prime}}{2}-\theta^{\prime}\right) \tan \phi^{\prime}\right\}\right] \\
& +c^{\prime}\left[\left(\frac{\cos \phi^{\prime}}{1-\sin \phi^{\prime}}+\frac{1}{\tan \phi^{\prime}}\right)\right. \\
& \left.\times \exp \left\{2\left(\frac{\pi}{4}-\frac{\phi^{\prime}}{2}-\theta^{\prime}\right) \tan \phi^{\prime}\right\}-\frac{1}{\tan \phi^{\prime}}\right]
\end{aligned}
$$

になる. また，Fig.A·4 に示すように，ある点でのせん 断抵抗合応力を $p$ とし, $p$ が半径方向となす角度を $\lambda$ とすると, Fig. A.5において幾何学的関係を調べること により,

$$
\begin{aligned}
& p \sin \lambda=\left(c^{\prime} \cos \phi^{\prime}+\sigma_{m}^{\prime} \sin \phi^{\prime}\right) \sin \phi^{\prime} \\
& p \cos \lambda=\left(-c^{\prime} \sin \phi^{\prime}+\sigma_{m}^{\prime} \cos \phi^{\prime}\right) \cos \phi^{\prime}
\end{aligned}
$$

が得られる.また， $p$ の鈆直成分を $p^{\prime}$ とする，

Fig. A・4 から

$$
p^{\prime}=-p \cos \left(\theta^{\prime}+\lambda\right)
$$

が成り立つ。

式 $(\mathrm{A} \cdot 9)$ （A·11）を用いて $p^{\prime}$ を計算し, さらに $p^{\prime}$ をすべり面全体にわたって積分することにより，すべり 面に作用する鉛直方向の力の合力 $T$ が次式のように求 められる。

$$
T=\int p^{\prime} d s=\int_{\pi / 4-\phi^{\prime} / 2}^{\pi / 2} p^{\prime} R d \theta^{\prime}=\gamma R^{2} I_{1}\left(\phi^{\prime}\right)+c^{\prime} R I_{2}\left(\phi^{\prime}\right)
$$

ただし，

$$
I_{1}\left(\phi^{\prime}\right)=\frac{1}{\left(4 \tan ^{2} \phi^{\prime}+1\right)^{2}}\left\{2 \tan \phi^{\prime} \sin \left(\frac{\pi}{4}+\frac{\phi^{\prime}}{2}\right)\right.
$$

$$
\begin{aligned}
& \left.-\cos \left(\frac{\pi}{4}+\frac{\phi^{\prime}}{2}\right)\right\} \cdot\left[\left(2 \tan \phi^{\prime} \sin \phi^{\prime}+\cos \phi^{\prime}\right)\right. \\
& \times \exp \left\{-\left(\frac{\pi}{2}+\phi^{\prime}\right) \tan \phi^{\prime}\right\} \\
& \left.+2 \tan \phi^{\prime} \cos \left(\frac{\pi}{4}+\frac{\phi^{\prime}}{2}\right)-\sin \left(\frac{\pi}{4}+\frac{\phi^{\prime}}{2}\right)\right] \\
& -\frac{1}{4 \tan ^{2} \phi^{\prime}+1}\left\{\frac{1}{2} \tan \phi^{\prime}\left(\cos 2 \phi^{\prime}-\sin \phi^{\prime}\right)\right. \\
& \left.-\frac{1}{4}\left(\frac{\pi}{2}+\phi^{\prime}-\sin 2 \phi^{\prime}-\cos \phi^{\prime}\right)\right\} \\
I_{2}\left(\phi^{\prime}\right)= & -\frac{1+\sin \phi^{\prime}}{\sin \phi^{\prime}\left(4 \tan \phi^{\prime}+1\right)} \\
& \cdot\left[\left(2 \tan \phi^{\prime} \sin \phi^{\prime}+\cos \phi^{\prime}\right)\right. \\
& \times \exp \left\{-\left(\frac{\pi}{2}+\phi^{\prime}\right) \tan \phi^{\prime}\right\} \\
& \left.+2 \tan \phi^{\prime} \cos \left(\frac{\pi}{4}+\frac{\phi^{\prime}}{2}\right)-\sin \left(\frac{\pi}{4}+\frac{\phi^{\prime}}{2}\right)\right] \\
& +\frac{1}{\tan \phi^{\prime}}\left\{1-\cos \left(\frac{\pi}{4}+\frac{\phi^{\prime}}{2}\right)\right\} \ldots \cdots \cdots(\mathrm{A} \cdot 13)
\end{aligned}
$$

である。

\section{（4）埋設管に作用する土圧}

埋設管に作用する土圧はすべり面に册まれる領域の土 の重量 $W$ とすべり面に作用する鉛直方向の力 $T$ の和で ある. 式 $(\mathrm{A} \cdot 2)$, 式 $(\mathrm{A} \cdot 12)$, および円弧の半径 $R$ の 值に式 $(A \cdot 1)$ を用いて土圧を計算し, 土被り圧で正規 化すると，

$$
\begin{aligned}
\frac{\sigma_{v}^{\prime}}{\gamma H}= & \frac{W+2 T}{\gamma H B_{c}}=\frac{\left(H+B_{c} / 2\right)^{2}}{H B_{c}} F_{1}\left(\phi^{\prime}\right) \\
& +\frac{H+B_{c} / 2}{H B_{c}} \cdot \frac{2 c^{\prime}}{\gamma} F_{2}\left(\phi^{\prime}\right)+\frac{H+(1 / 2-\pi / 8) B_{c}}{H}
\end{aligned}
$$

になる、ただし， $F_{1}\left(\phi^{\prime}\right), F_{2}\left(\phi^{\prime}\right)$ は

$$
\begin{aligned}
F_{1}\left(\phi^{\prime}\right)= & \frac{2 I_{1}\left(\phi^{\prime}\right)}{\sin ^{2}\left(\pi / 4+\phi^{\prime} / 2\right)}+\frac{2}{\sin \left(\pi / 4+\phi^{\prime} / 2\right)} \\
& -\tan \left(\frac{\pi}{4}-\frac{\phi^{\prime}}{2}\right)-\frac{\pi / 4+\phi^{\prime} / 2}{\sin ^{2}\left(\pi / 4+\phi^{\prime} / 2\right)}, \\
F_{2}\left(\phi^{\prime}\right)= & \frac{I_{2}\left(\phi^{\prime}\right)}{\sin \left(\pi / 4+\phi^{\prime} / 2\right)} \cdots \cdots \ldots \ldots \ldots \ldots \ldots \ldots \ldots \ldots \ldots \ldots \ldots \ldots \ldots
\end{aligned}
$$

であり， $I_{1}\left(\phi^{\prime}\right), I_{2}\left(\phi^{\prime}\right)$ には式 $(\mathrm{A} \cdot 13)$ を用いる. 本文の Fig. 1 にこれらの值が示されている.

\section{参 考 文 献}

1) 湯浅欽史：地下埋設暗きょに関する予備的室内実験，土 木学会論文集, No. 83, pp. 11 20, 1962 年7月.

2) 松尾 稔 - 掘内孝英: Marston-Spangler 理論の設計への 適用に関する研究, 土質工学会論文報告集, Vol. 15, No. 2, pp. 97 107, 1975 年 6 月.

3) Yoshikoshi, W. : Vertical earth pressure on a pipe in the ground, Soils and Foundations, Vol.16, No.2, pp. 31 41, June, 1976. 
4) Takagi, N., Nishio, N., Yoneyama, K. and Shimamura K. : Development of a strain measurement system for soils and its application to sand around a buried pipe, Soils and Foundations, Vol.23, No. 3, pp. 65 79, Sep. 1983.

5）加室 昂・大津賀久夫 - 高木貞人 - 吉田賢太郎：導管お よび受防護におよぼす地盤沈下の影響について(第 2 報)， 東京ガス (株) 総合研究所報告, No. 17, pp. 149 163, 1972 年.

6) Spangler, M. G. : Soil Engineering, International Textbook Co., Scranton, Pennsylvania, pp. 396 418, 1963.

7）山口柏樹：埋設構造物（管）の沈下と変形, 土質工学会 関西支部, pp. 93 108, 1976 年 2 月.

8) Meyerhof, G. G. and Adams, J. I. : The ultimate uplift capacity of foundations, Canadian Geotechnical J., Vol. 5, No. 4, pp. 225 244, 1968.

9) Trautmann, C.H., O'Rourke, T.D. and Kulhawy, F.H. : Uplift force-displacement response of buried pipe, J. of Geotechnical Engineering, ASCE, Vol.111, No. 9, pp. 1061 1076, Sep., 1985.
10) Ladanyi, B. and Hoyaux, B. : A study of the trapdoor problem in a granular mass, Canadian Geotechnical J., Vol. 6, No. 1, pp. 1 14, 1969.

11) Matsuo, M. : Study on the uplift resistance of footing ( I ), Soils and Foundations, Vol. 7, No. 4, pp. 1 37, 1967.

12）勝見 雅・西原 晃：アースアンカーの引抜き抵抗に関 する基礎的研究, 土木学会論文報告集, No. 276 , pp. 65 ～76, 1978 年 8 月.

13) Vesić, A.S. : Breakout resistance of objects embedded in ocean bottom, J. of the Soil Mechanics and Foundations Division, ASCE, Vol.97, No. SM9, pp.1183 1205, Sep. 1971.

14) Vesić, A. S. et al. : Engineering properties of nuclear craters, Technical Report No. 3-699, Report 2, U.S. Army Engineer Waterways Experiment Station, Vicksburg, Miss., 123 pp., 1965.

15）山口柏樹：土質力学 (全改訂), 技報堂出版, pp. 214 216, 1984 年 2 月.

(1987.4.17 - 受付) 